\title{
Nature Protection and Sustainable Tourism Interaction in Selected Ramsar Sites in Vojvodina (Northern Serbia)
}

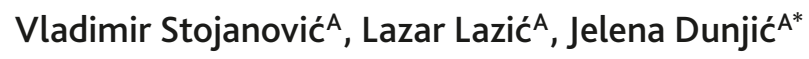 \\ Received: January 16, 2018 | Revised: July 20, 2018 | Accepted: July 21, 2018
}

DOI: 10.5937/gp22-16637

\begin{abstract}
This paper explores wetland-based tourism in four Ramsar sites in northern Serbian province Vojvodina, as well as a connection between tourism and nature protection. These regions are of great importance for Vojvodina, especially from the point of view of ecosystem services, because $83.3 \%$ of its territory are agricultural areas. Explored Ramsar sites were designated in period from 2004 to 2008 and they have been included in many plans as important areas for tourism development. However, the level of tourism development in these sites is not uniform because it depends on variety of factors such as touristic attractions value, engagement of nature protection managers in tourism development, and level of nature degradation and protection. The main objective of this paper is to determine the interconnection between nature degradation, nature protection and tourism development in selected Ramsar areas of Vojvodina, based on the Internal data of protected area managers, Report on the state of the environment and the scope of tourism development (infrastructure, services, development plans).
\end{abstract}

Keywords: Ramsar Sites; Vojvodina; nature protection; sustainable development; ecotourism

\section{Introduction}

The Ramsar Convention (The Convention of Wetlands of International Importance) is one among contemporary initiatives in natural assets protection around the globe, which is interrelated with the most endangered habitats in the world - wetland habitats, and is a core part of the international biodiversity governance system (Mauerhofer et al., 2015). The convention highlights the significance of protection and wise utilization of wetlands (Matthews, 2013; Hettiarachchi, 2015). The need for wise utilisation is perceived in large number of services that such habitats may provide (Smart \& Canters, 1991; Asaad et al., 2017, Verhoeven, 2014). Primarily, the services include: water supply, water purification (Ostrovskaya et al., 2013), recreational facilities and tourism. Wetlands preservation and pro- tection, by means of Ramsar Convention and other activities, should provide the aforementioned services with the aim of achieving the wellbeing of the local population and communities (Ramsar Convention Secretariat, 2010; Ostrovskaya et al., 2013; Bego \& Malltezi, 2011). There were 2,293 declared Ramsar sites in the world, covering the total area of $225,418,823$ ha by January 2018 (http://www.ramsar.org/).

Unspoiled protected nature is coming under growing consumer demand for recreation (Mauerhofer, 2011). As a form of international status in nature protection, the Ramsar sites are types of tourist attractions similar to other protected areas. They have been promoted and sold as tourist attractions by tourism industry (Wall Reinius \& Fredman, 2007). Pro-

\footnotetext{
A Department of Geography, Tourism and Hotel Management, Faculty of Sciences, University of Novi Sad, Trg Dositeja Obradovića 3, 21000 Novi Sad, Serbia; vladimir.stojanovic@dgt.uns.ac.rs, lazar.lazic@dgt.uns.ac.rs, dunjicjelena1@gmail.com

* Corresponding author: Jelena Dunjić, e-mail: dunjicjelena1@gmail.com
} 
tected areas and tourism interaction consist of benefits (e.g. income from turnover and ticket sales) and threats (e.g. excessive numbers of tourists) that tourism brings to the protected areas (Holden, 200o). Protected areas are significant tools in realisation of sustainable tourism goals, thus, the countries with larger percentage of their territories being under protection are considered more developed countries in that sense (Stojanović, 2011). Tourism industry may and must support natural assets of wetlands through a series of activities (waste reduction, support to government and non-government sectors in protection, raising tourists' awareness on nature protection through marketing activities), since the industry would benefit in return (UNWTO, 2010).

The beginnings of the Ramsar protected sites in Serbia date back to the year 1977 when the country was a federal constituent part of the SFR Yugoslavia. After going through numerous political turbulences and obtaining its independence in 2006, the Republic of Serbia informed the Ramsar Secretariat that it is willing to proceed with its rights and responsibilities regarding international agreements, which were signed while Serbia was a federal part of former countries (http://www.ramsar.org/). There have been ten Ramsar sites declared on the territory of Serbia, out of which there have been eight on the territory of Vojvodina, its northern province. The presence of the wetlands has been conditioned by complex geographical features, first of all geology, relief and pedology factors (Lazić et al., 2008). Wetlands are important for preservation of the mosaic of habitats in Vojvodina, which is characterised by high diversity of species. Their protection is performed within the network of protected sites pursuant to the Law on Nature Conservation. Eight out of ten protected sites are included into the Ramsar List of Protected Sites of International Importance. According to professional evaluation, there are also 20 sites that also may meet the Ramsar Criteria (Panjković \& Stojnić, 2011).

The analysis of the overall importance of these protected sites also involves tourism, which is incorporated into their management strategies and plans. The aim of this paper is to compare the achieved tourism development level and its inclusion into the protection of four Ramsar sites: Gornje Podunavlje (declared in 2007), Labudovo okno (2006), Slano Kopovo (2004) and Zasavica (2008). These sites have been included into the Ramsar list of protected sites of international importance for over ten years. These Ramsar sites are characterized by similar conditions of the environment and the characteristics of the area, which enables the formation of a similar tourist offer in each of them. These are mainly areas of alluvial planes of the rivers, wet meadows, salt marshes, as well as areas where water is a significant segment of the environment (rivers, canals, ponds, lakes). Managers of these protected areas are, even declaratively, committed to achieving the goals of tourism development, as can be seen through the construction of tourism infrastructure (thematic paths, observation posts, visitor centers).

\section{Description of the researched sites}

Four Ramsar sites in Vojvodina - Gornje Podunavlje (2007), Slano Kopovo (2004) Zasavica (2008) and Labudovo okno (2006), out of the total eight in the Province (Figure 1), were declared after the democratic changes in Serbia in 2000, when Serbia embarked on its EU Integration path and enacted new laws on environment and nature protection. Each of these geographical areas has been connected with the flows of three large rivers: the Danube, the Tisza, and the Sava dating back to either their near or far geological past.

Gornje Podunavlje $(22,480 \mathrm{ha})$ is situated on the north-western periphery of Vojvodina, where it covers low alluvial plains with numerous meanders, lakes and marshes along the flow of the Danube (about 35 $\mathrm{km})$. It consists of three landscape units: Karapandža, Monoštorski and Apatinski rit of which only the last has preserved genuine features of the flood plain (Stojanović, 2005). This area is an important centre of landscape, ecosystem and species varieties. The wealth of plants consists of about 1,0oo species, among which there are extremely endangered species listed in the Red book of flora in Serbia, e.g. winter aconite (Eranthis hyemalis), water violet (Hottonia palustris) and mare's tail (Hippuris vulgaris). The total known number of ornithofauna is 230 . The member of the group is also the rare and endangered species of white-tailed eagle (Haliaeetus albicilla). Also, Gornje Podunavlje is the largest habitat of red deer (Cervus elaphus) in Serbia (Panjković, 2000).

Slano Kopovo ( $976 \mathrm{ha}$ ) is a paleo-meandre of the Tisza river, i.e. a lake created by the activity of the river (Marković et al., 1997). It is situated in the central part of Vojvodina. The lake was formed during the last glacial phase and at the beginning of the Holocene, when the river had large outflow due to the glacier melting (Lazić et al., 2008). The lake is situated in the deepest part of meander depression, which is covered by soil of high salinity. Flora species in Slano Kopovo have a characteristic and valuable species of particular saline group belonging to class Thero-Salicornietea. The val- 


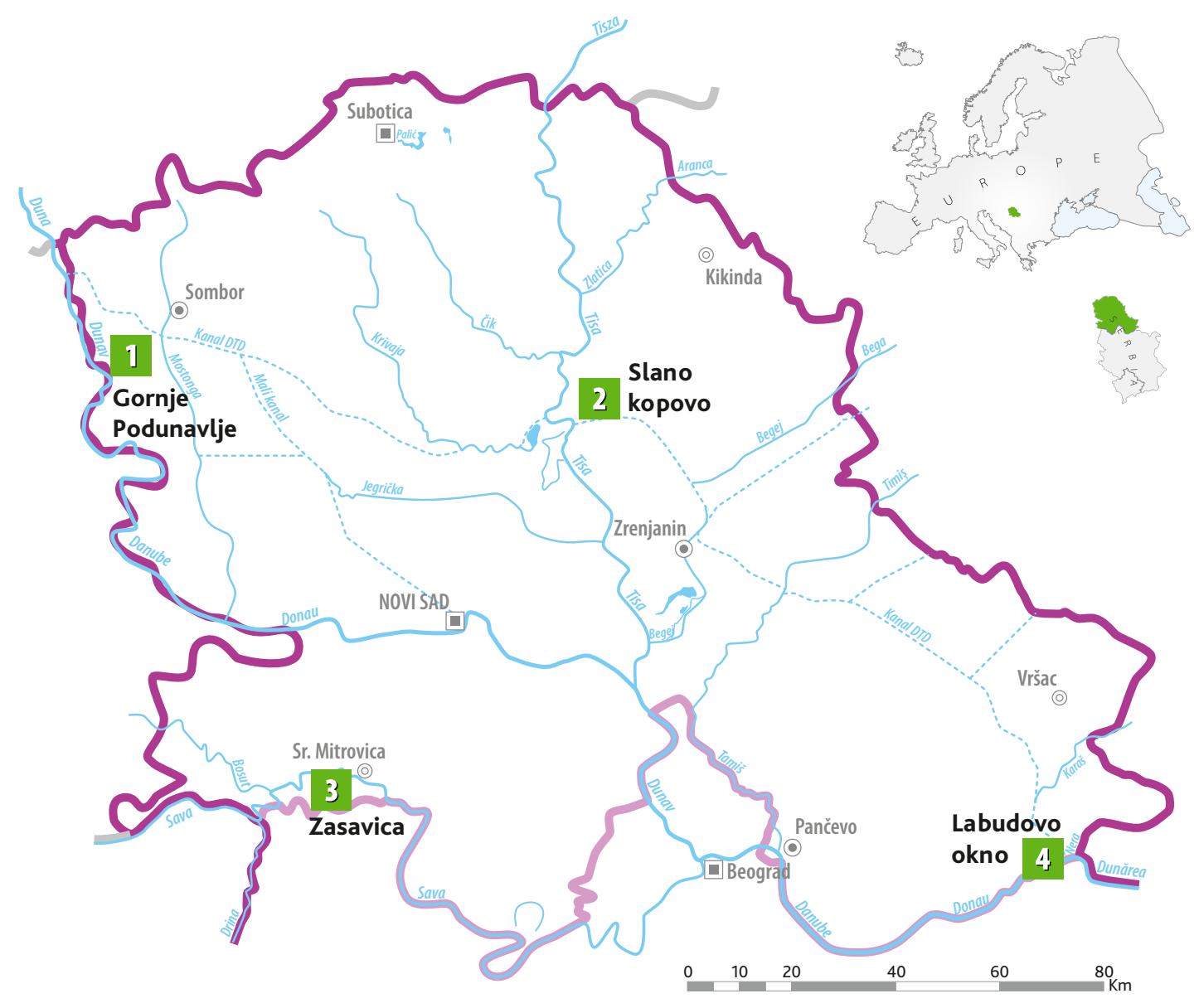

Figure 1. Researched and other Ramsar sites in Vojvodina

ue of this vegetation type is recognised at both national and international level. This Ramsar site is the most versatile bird habitat in Serbia with 200 registered species. The most prominent species are: cranes, ducks and geese (Vig et al., 2012).

Labudovo okno (3,733 ha) stretches along the left bank of the Danube river in the furthest south-eastern part of Vojvodina. Within the borders of the Ramsar site there are several river islands, whose dimensions have altered during the constructon of Đerdap lake downstream from the area. It is the construction of this accumulation that had impact of the low flow and high water level of the Danube, which further caused the submerging of low alluvial terrain along the river course and created new marsh habitats with wet meadows and steppe pastures. River shoals are ideal areas for fish hatching, migratory trails and winter homes. Labudovo okno is one of the most relevant wetland birds' nesting point in Serbia, as well as their invaluable winter home in Pannonian plain (Puzović et al., 2014).

Zasavica (1,913 ha) comprises plain areas in the south-western part of Vojvodina, which are shaped by two rivers the Sava and the Drina regarding their relief features. The main hydrological value of this area is the flow of Zasavica and its tributary Batar. Zasavica is one of the last intact marsh areas in Serbia (Lazić et al., 2008).The natural habitat conditions include rare, endangered and significant flora species such as: greater spearwort (Ranunculus lingua) and water violet (Hottonia palustris), mare's-tail (Hippuris vulgaris), Kievan nettle (Urtica kioviensis) (Igić et al., 2001). Along the Danube flow there are numerous species of white and yellow water lily, and the last one habitat of mud minnow (Umbra krameri). There are around 180 bird species, out of which 90 species nest in Zasavica.

\section{Data sources and Methods}

Tourism development in protected areas, particularly in the Ramsar sites, implies fulfilling certain criteria for natural assets protection, which are applied in cases when the nature is either polluted or degrad- ed. Therefore, the first step in this research is devoted to field work and interviews with management representatives in the Ramsar sites. Secondary data sources rely on internal documents of the Institute for Nature 
Conservation of Vojvodina Province, with its seat in Novi Sad and information retrieval from the Report on Nature Condition in the Autonomous Province of Vojvodina for the period 2010-2014 (2015) and Medium-term Programme of Nature Assets Protection for the period 2011-2020 (2011). First, the data on the tourism development scope have been collected through fieldwork. Then, the data have been collected on tourism development projects in tourism organisations of the municipalities where the protected sites are located.

\section{Results and Discussion}

The key anthropogenic impact on protected areas in the Ramsar sites was accomplished during the $19^{\text {th }}$ and $2 \mathrm{O}^{\text {th }}$ centuries, with a trend of huge melioration works that were performed in Vojvodina at that time. Such activities influenced the changes in the protected areas: embankment construction, drainage of floodplains, changes in river flows, and construction of canal network. Yet, the level of natural resources violations has not reached the critical value at which the resources could be defined as completely lost. With the application of adequate protection programmes the resources could be renewed and returned to their former condition.

Gornje Podunavlje is the most endangered by melioration works, embankment construction and construction of canal network which has intersected natural river flows. Karapandža and Monoštorski rit are the places that have been struck the hardest, since both have been separated by embankments from the natural flow of the Danube. Poplar plantations have been systematically replacing the areas of the old autochthonous forests of white poplar for decades. These areas are accessible to tourists, but they are not as attractive as some others, because, to some extent, they lost the original properties of typical humid habitats (Stojanović, 2005), on which the quality ecotourism offer is based. Many types of activities take place in wetlands, such nature-based tourism, including ecotourism (Do et al, 2015). Also, tourism could draw
This paper is based on the hypothesis that environmental factors and natural phenomena are crucial for the protection of Ramsar sites, and also their most important tourism potential. Therefore, comparative analysis between degradation-protection-sustainable tourism, examines what consequences degradation and protection of nature could have on the development of sustainable or ecotourism in the Ramsar sites. Furthermore, through the tourist turnover in the Ramsar sites and the analysis of the measures undertaken in the development of tourism, an assessment is made of the current level of tourism development.

attention to the necessity of restoring the original features to these habitats, because ecotourism and sustainable development enlist tourism to help maintain and enhance environmental integrity and attractiveness (Farrell \& Runyan, 1991). Despite all this, Gornje Podunavlje with Apatinski rit remains one of the most preserved wetlands in Serbia.

Slano Kopovo is endangered due to the disturbed water regime within the borders of the protected area that causes the essential value of this area, Slano Kopovo lake, to dry up frequently. Besides, there is the problem of often ploughing of certain enclaves in wet meadows, pastures, and turning them into agricultural soil. In case that this natural phenomenon is lost, the tourist attraction of Slano Kopovo would be questionable. Observation of birds, which depend on this aquatic ecosystem, is the most represented segment in the tourism offer of Slano Kopovo. Numerous studies have shown that birdwatchers are interested in the presence of indigenous birds, but also in natural features, habitat attractiveness, the presence of non-avian wildlife and native plants, escape from urban areas (Chen \& Chen, 2015), so, for what Slano Kopovo already possesses, but which is at the same time jeopardized.

Labudovo okno is endangered due to the visitors' negligence and high level of poaching of wetland birds and illegal fishing. Preventing these negative impacts can be achieved through more intensive tourism

Table 1. Dominant factors of nature endangerment in the Ramsar sites

\begin{tabular}{|l|c|c|c|c|}
\hline & Gornje Podunavlje & Slano Kopovo & Labudovo okno & Zasavica \\
\hline Disrupted water regime & $\mathrm{X}$ & $\mathrm{X}$ & & $\mathrm{X}$ \\
\hline Embankment construction & $\mathrm{X}$ & $\mathrm{X}$ & & \\
\hline Ploughing meadows and pastures & & & $\mathrm{X}$ & \\
\hline Poaching and illegal fishing & & & \\
\hline
\end{tabular}

Source: Internal data of protected area managers; Report on Nature Condition in the Autonomous Province of Vojvodina for the period 2010-2014,2015 
development, as it turned out that in some protected areas the presence of traps and hunting squads is less by $25-50 \%$, where the concentration of tourists and researchers is increased (McNeilage, 1996).

Despite having been exposed to strong anthropogenic impact during the 2oth century, Zasavica managed to preserve autochthonous features of a wetland. Inappropriate water regime has been a long threat that has kept jeopardizing this area. The problem has been caused by poor melioration and hydro-technical works and has been persistent today creating sediments and silt. As far as national level of protection is concerned, the management of the protected area has succeeded in reducing negative influence by intervening and preventing further deterioration of this wetland.

Tourism industry is an essential partner in all plans and strategic documents regarding nature protection in Serbia. The Law on Nature Conservation highlights the necessity of defining the conditions and measures for nature conservation within basic postulates and management programmes for tourism and other industries. Moreover, it has been highlighted that the use of natural resources and protected areas is permitted pursuant to the Law ("Official Gazette RS", 36/2009; 88/2010; 91/2010 and 14/2016). According to the conservation decree, protected areas as the base of protection for the Ramsar sites on national level shall be provided with the following: facilities for ecotourism in the Nature Reserve Deliblatska peščara, whose part is Labudovo okno; tourism and education facilities in Zasavica, as well as observation post with access paths in Slano Kopovo (Stojanović, et al, 2011). Finally, numerous suggested guidelines to stimulate tourism development in wetlands from The Ramsar Convention on Wetlands and World Tourism Organization (UNWTO), should also offer additional enhancement in tourism development of the researched Ramsar sites (Wetland tourism: A great Experience, Responsible tourism supports wetlands and people, 2012).

Plans and strategic analyses of tourism development in Serbia have recognised central identity of Vojvodina under the slogan: "Water abundance, Pannonian pleasure". It implies that rivers and lakes are the main tourism product and also that Vojvodina as a cluster is linked to the nature. If we personalise Vojvodina, we may say that it is considered not only as a water admirer, but also as being hospitable and creative. The symbol of Vojvodina is the Danube river. This short analysis clearly refers to the fact that the features of Vojvodina as a tourism destination may be recognised in the Ramsar sites, but the current turnover is not in concordance with the potential (Table 2).

The link between nature conservation and tourism in the Ramsar sites has been realised through the offer of educational and ecology trails. Gornje Podunavlje has three such trails in the total length of eight kilometres (Karapandža, Bestrement, Štrbac). Slano Kopovo offers two educational trails (Southern and Northern). Zasavica also has two educational trails in the total length of nine kilometres (Big and Small trail). Visitors' centres as important segments of ecotourism offer are found in the offers of both Slano Kopovo and Zasavica. Apart from these, tourism industry in the Ramsar sites has been encouraged by other segments within the offer (Table 3).

According to the present observations, there is no negative impact of tourism on natural values in the four Ramsar sites. According to management of these

Table 2. Number of visitors in the researched Ramsar sites

\begin{tabular}{|l|c|c|c|c|c|c|}
\hline & 2010 & 2011 & 2012 & 2013 & 2014 & Total \\
\hline Gornje Podunavlje & 2,300 & 400 & 250 & 400 & 400 & 3,750 \\
\hline Slano Kopovo' & - & - & - & - & - & - \\
\hline Labudovo okno & 4,204 & 2,575 & 3,614 & 4,439 & 3,647 & 18,479 \\
\hline Zasavica & 18,000 & 30,000 & 80,000 & 40,000 & 30,000 & 198,000 \\
\hline
\end{tabular}

${ }^{1}$ Data not available

2 The data refer to the visits to SNR Deliblatska peščara in which the Ramsar site Labudovo okno is only a small part Source: Internal data of protected area managers

Table 3. Representation of tourism content, services and development plans

\begin{tabular}{|l|c|c|c|c|}
\hline & Gornje Podunavlje & Slano Kopovo & Labudovo okno & Zasavica \\
\hline Visitors' centre & & $X$ & $X$ \\
\hline Educational and eco-trails & $\mathrm{X}$ & & $\mathrm{X}$ \\
\hline Camps & $\mathrm{X}$ & & $\mathrm{X}$ \\
\hline Marines & $\mathrm{X}$ & & \\
\hline Internet website (Information on visits) & $\mathrm{X}$ & $\mathrm{X}$ & & \\
\hline Tourism Strategy & $\mathrm{X}$ & & & $\mathrm{X}$ \\
\hline
\end{tabular}


four protected areas, the number of visitors is still small and the groups are at very specific locations under surveillance. The construction of tourist facilities, which are mainly interpreting boards, rest areas and small visitor centers, are not carried out in vulnerable and sensitive locations. However, this should be taken with precaution since sustainable tourism indicators have not been applied.

\section{Conclusion}

Disrupted water regime and embankment construction pose a serious danger to the protected areas of the explored Ramsar areas. These factors endanger the greatest value of these areas, which are wetlands with all the accompanying natural phenomena - canals, lakes, ponds, habitats of rare and endangered plant and animal species. At the same time, these natural phenomena are the most important resource in the development of sustainable tourism (ecotourism). With the loss of natural phenomena of the Ramsar areas, the potential for tourism development would be permanently lost. Further it is necessary that managers, local authorities and tourism workers recognize the power of tourism in popularizing nature protection.

Tourism is still in its early development phase according to the achieved turnover and tourism infrastructure. Increased turnover in certain Ramsar sites, such as Zasavica, confirms that tourism may become the opportunity for other areas too, primarily because tourism activities are similar in character and potential. Directing economic development towards tourism could divert local communities from the activi- ties which are traditionally present in the area but may significantly degrade it (e.g. intensive agriculture).

Further enhancement of positive connections between nature conservation and tourism should insist on: (1) encouraging the management in protected nature areas to seriously devote to tourism industry, since the previous efforts were fruitful, e.g. the initiative for Gornje Podunavlje to apply and finally obtain European Charter for Sustainable Tourism in Protected Areas (EUROPRAC); (2) stronger connections between nature values and tourism offer design (clear identification of species, habitats, and ecosystems included in the tourism offer) and (3) development of ethical code for tourists in order to raise consciousness on necessity of nature and environment conservation.

Tourism development plans in the Ramsar areas should be based on current research of tourism market potentials. Unfortunately, large numbers of potential tourists in Vojvodina despite the fact that they show interest in the protected areas do not visit such areas. The reasons are found in undeveloped offer for tourism stay in protected areas, poor strategic positioning and poor tourism marketing.

\section{Acknowledgement}

This research was supported by the Project "Geotransformation of the area of Vojvodina in the service of regional development" 142-451-25811 / 2017-04 of Provincial Secretariat for Higher Education and
Scientific Research (Autonomous Province of Vojvodina) and Serbian Ministry of Education, Science, and Technological Development of Republic of Serbia (Project III 43005).

\section{References}

Asaad, I., Lundquist, C. J., Erdmann, M. V., \& Costello, M. J. (2017). Ecological criteria to identify areas for biodiversity conservation. Biological Conservation, 213, 309-316.

Bego, F., \& Malltezi, J. (2011). Ecotourism opportunities and challenges in Butrint, Albania, a unique UNESCO and Ramsar site. Journal of Coastal Research, Special Issue no. 61, 150-157.

Chen, L. J., Chen, W. P., 2015. Push-pull factors in international birders' travel. Tourism management, 48. 416-425.
Do, Y., Kim, S. B., Kim, J. Y., Joo, G. J. 2015. Wetland based tourism in South Korea: who, when and why. Wetland ecology management, 23. 779-787.

Farrell, B., Runyan, D. 1991. Ecology and tourism. Annals of Tourism Research, 18. 26-40.

Hettiarachchi, M., Morrison, T.H., McAlpine, C. 2015. Forty-three years of Ramsar and urban wetlands. Global Environmental Change, 32. 57-66.

Holden, A. 200o. Environment and Tourism, Routledge Introductions to Environment Series. Routledge, Taylor \& Francis Group, London and New York. 
Igić, R., Stojšić, V., Vukov, D., Panjković, B. 2001. Rare and protected plants of Zasavica river. Zasavica 2001. 42-48pp.

Institute for nature conservation of Vojvodina province. 2011. Medium-term Programme of Nature Assets Protection for the period 2011-2020 (in Serbian)

Institute for nature conservation of Vojvodina province. 2015. Report on Nature Condition in the Autonomous Province of Vojvodina for the period 20102014 (in Serbian)

Lazić, L., Pavić, D., Stojanović, V., Tomić, P., Romelić, J., Pivac, T., Košić, K., Besermenji, S., Kicošev, S., Đarmati, Z., Puzović, S., Đureković-Tešić, O., Stojanović, T., Marić, B., Vig, L., Panjković, B., Habijan-Mikeš, V., Sabadoš, K., Delić, J., Kovačević, B., Stojšić, V., Korać, J. 2008. Protected areas and ecotourism of Vojvodina. Department of Geography, Tourism and Hotel Management, Faculty of Sciences, Novi Sad. (in Serbian)

Marković, S., Lukač, Š., Kicošev, S. 1997. Slano Kopovo. Zaštita prirode, 48-49. 321-326. (in Serbian)

Matthews, G.V.T. 2013. The Ramsar Convention on Wetlands: its History and Development. Ramsar Convention Bureau, Gland Switzerland.

Mauerhofer, V., Kim R. E, \& Stevens, C. (2015). When implementation works: A comparison of Ramsar Convention implementation in different continents. Environmental Science and Policy, 51, 95-105.

Mauerhofer, V. (2011). A bottom-up 'ConventionCheck' to improve top-down global protected area governance. Land Use Policy, 28, 877-886

McNeilage, A. 1996. Ecotourism and mountain gorillas in the Virunga Volcanoes. In: V.J. Taylor and N. Dunstone (eds.) The Exploitation of Mammals Population, pp. 334-344. London, UK: Chapman \& Hall.

Ostrovskaya, E., Douven, W., Schwartz, K., Pataki, B, Mukuyu, P., \& Kaggwa, R.C. (2013). Capacity for sustainable management of wetlands: Lessons from the WETwin project. Environmental Science and Policy, 34, 128-137.

Panjković, B. 200o. Significant Biodiversity Components at Apatinski and Monoštorski rit (YU). Limnological reports: Proceedings of the 33th IAD Conferencein Osijek, Croatia, 3-9 September 2000.

Panjković, B., Stojnić, N. 2011.Biodiversity and protected areas. In: Puzović, S., Radovanović-Jovin, $\mathrm{H}$. [eds.] Environment in the Autonomous Province of Vojvodina. Provincial Secretariat for Urban Planning, Construction and Environmental Protection. Novi Sad.

Puzović, S., Đureković-Tešić, O., Marić, B., Stojanović, T., Vig, L., Stojnić, N., Perić, R., Ham, I., Lazić, L.,
Stojanović, V., Pavić, D., Vasić, I., Olđa, M. 2014. Labudovo okno Ramsar Site. Provincial Secretariat for Urban Planning and Environmental Protection, Autonomous Province of Vojvodina, Novi Sad.(in Serbian)

Ramsar Convention Secretariat 2010. Wise use of wetlands: Concepts and approaches for the wise use of wetlands. Ramsar handbooks for the wise use of wetlands, 4th edition, vol. 1. Ramsar Convention Bureau, Gland Switzerland.

Smart, M. \& Canters, K.J. (1991). Ramsar participation and wise use. Landscape Urban Plann., 20, 269-274.

Stojanović, V. 2005. Sustainable development in special nature reserves of Vojvodina. Department of Geography, Tourism and Hotel Management, Faculty of Sciences, Novi Sad. (in Serbian)

Stojanović, V. 2011. Tourism and sustainable development. Department of Geography, Tourism and Hotel Management, Faculty of Sciences, Novi Sad. (in Serbian)

Stojanović, V, Lazić, L., Pavić, D., Panjković, B., Košić, K., Dragin, A., Stankov, U., Jovanović, M., Pantelić, M., Stamenković, I., \& Ivanović, Lj. (2011). A feasibility study on the development of ecotourism in the protected natural areas of Vojvodina (with special emphasis on Ramsar areas). Department of Geography, Tourism and Hotel Management, Faculty of Sciences, Novi Sad. (in Serbian)

The Law on Nature Conservation.Official Gazette RS. 36/2009; 88/2010; 91/2010 i 14/2016. (in Serbian)

UNWTO 2010. Tourism and Biodiversity - Achieving Common Goals Towards Sustainability, World Tourism Organization, Madrid, Spain.

Verhoeven, T.A. J. (2014). Wetlands in Europe: Perspectives for restoration of a lost paradise. Ecological Engineering, 66, 6-9.

Vig, L., Đureković-Tešić, O., Marić, B., Stojanović, T., Puzović, S., Stojnić, N., Knežev, N., Lazić, L., Stojanović, V. 2012. Slano Kopovo Ramsar Site. Provincial Secretariat for Urban Planning and Environmental Protection, Autonomous Province of Vojvodina, Novi Sad.(in Serbian)

Wall Reinius, S., Fredman, P. 2007. Protected Areas as Attractions. Annals of Tourism Research 34- 4, 839854 .

Wetland tourism: A great Experience. Responsible tourism supports wetlands and people. The Ramsar Convention on Wetlands, Gland, World Tourism Organization (UNWTO), Madrid, 2012.

http://www.ramsar.org/ 